\title{
Australian Parental Incomes: Women and Men, Couples and Singles
}

\author{
Marty Grace \\ Victoria University, Australia
}

\begin{abstract}
Families caring for dependent children need time, income and services in order to carry out the important function of raising children, an essential social and economic activity that ensures the future survival and wellbeing of the society. This article focuses on income, and reports on a piece of original sociodemographic research that used unpublished Australian Bureau of Statistics (ABS) data to explore the incomes of Australian women and men in different family circumstances. The research shows that couple family men have markedly higher incomes than couple family women, single fathers and single mothers. We need social policy that takes account of diversity of family forms; makes it possible for all families raising children to gather together adequate income; encourages gender equity; and acknowledges the raising of children as activity that benefits the whole community. Along with these requirements, social policy must recognise that caring for children takes time, and that the demands of children change over the lifecourse. The lifecourse considerations include the high demands on parental time in the early years; and recognition of change in roles and circumstances over time.
\end{abstract}

\section{Keywords}

Parents, Incomes, Policy

\section{Introduction}

In Australia we have seen extensive discussion in the community regarding paid maternity leave and 50:50 shared care following separation and divorce. Governments, communities and families are seeking new ways of arranging how we provide financially and care for our children. Community discussion and government policy initiatives are signs of a community seeking new structural arrangements that can support and reflect its beliefs, values and aspirations.

Australia's diverse families need to gather together the resources they need for wellbeing. These resources include income, time and services, and the wellbeing of all family members must be considered. The time required to provide care will usually come from adults and older children in households and extended families. Income comes from market earnings and government cash transfers. Services may be provided free of charge or subsidised by governments, as in the case of health and education, or purchased by households, as with gardening, car washing, prepared meals and home maintenance.

Copyright (C) 2008 Victoria University. This document has been published as part of the Journal of Business Systems, Governance and Ethics in both online and print formats. Educational and non-profit institutions are granted a nonexclusive licence to utilise this document in whole or in part for personal or classroom use without fee, provided that correct attribution and citation are made and this copyright statement is reproduced. Any other usage is prohibited without the express permission of the
This article focuses on income, and reports on a piece of original socio-demographic research that used unpublished Australian Bureau of Statistics (ABS) data to explore the incomes of Australian women and men in different family circumstances. The research was funded by a Victoria University Discovery Grant, and studied individual weekly income from all sources, 
revealing patterns of income inequality among women and men in couple families and single parent families.

\section{Previous Research}

In order to ensure the wellbeing of all family members, Australian women and men with responsibility for children require adequate time, income and services. Time to provide care for children, and services such as education and health are as important as income. All three must be considered together. Using time for unpaid work limits people's ability to use their time for income-earning. Income-earning increases the need for services such as childcare. Research in this area has included examination of time use survey data (Bittman \& Pixley 1997; Craig 2007, 2004, 2002; Gilding 1994; Ironmonger 2001), modelling of loss of lifetime earnings (Breusch \& E. Gray 2004; M. Gray \& Chapman 2001), modelling of costs of children (Australian Institute of Family Studies 2000; Percival \& Harding 2005), examination of mothers' labour market activity (Cass 2005; Walters 2002), findings that divorcing women are likely to be worse off financially than their ex-partners (Bittman \& Pixley 1997; O'Connor et al 1999; Wolcott \& Glezer 1995), studies of attitudes and preferences in relation to work and family (Evans \& Kelley 2001; Hakim 2003, 1996), and critical reflections on the concept of preferences (Morehead 2005; Probert \& Murphy 2001), studies of household income across different household types (ABS 2005), and international comparative modelling of mothers' ability to form an independent household (Shaver \& Burke 2003). Related research includes international studies of fertility rates (McDonald 2000) and qualitative research into the experiences of mothers following childbearing (Brown et al 1994).

Time spent caring for young children has both immediate and long-term impacts on mothers' incomes. Evidence indicates that younger children require more hours of care than older children, and that mothers of younger children earn less income than mothers of older children (Bittman \& Pixley 1997; Office of the Status of Women 2002). Pocock (2003) analysed 2001 census data and found that employment among both single and couple-family mothers increases gradually with age of youngest child. Gray and Chapman (2001) estimate that women with one child lose about 34\% of their lifetime earnings, increasing to around $40 \%$ for those with three children.

Some of the research above shows that in general, divorcing women are likely to be worse off financially than their ex-partners. However, it is not a simple story of gender, with men more likely than women to have high incomes. The Ministerial Taskforce on Child Support (2005) found that men as well as women post separation and divorce were much more likely to be on low incomes than people in the broader population. Men's low reported incomes post-divorce are often seen as an artefact of attempts to avoid child support obligations, and the Ministerial Taskforce on Child Support (2005) received many complaints alleging that payers minimised income in order to avoid child support obligations. However, Silvey and Birrell (2004) accessed Australian Tax Office records to compare preseparation with post-separation incomes and proposed the alternative idea that poverty and ongoing financial pressure contribute to separation and divorce, and that low post-separation incomes reflect low pre-separation incomes. This could of course mean that some men minimise their taxable incomes both before and after separation. In another take on men's low incomes following separation and divorce, Smyth et al (2003) suggests that fathers who share care of children equally with ex-partners typically change their working arrangements to increase flexibility, and suffer a consequent drop in earnings.

\section{Time Use and Income}

According to time use research, Australian women and men perform about the same amount of work. However, men are much more likely than women to be paid for their work. Australia's gendered division of labour is particularly striking when it comes to the work involved in caring for young children, with women tending to specialise in unpaid work and men tending to specialise in paid work (Bittman \& Pixley 1997; Craig 2002). Time use research has shown that caring for infants and young children takes at least the equivalent of a full working week. This work does not magically disappear if 
children go to formal childcare while parents are at their paid work. It has become apparent that the unpaid work must be done before and after paid work and at the weekends (Craig 2007). One of the great social policy challenges of the early $21^{\text {st }}$ century is to deal with the 'work/family issue' - the increasingly apparent desire of both women and men to participate meaningfully in both paid work and raising children (see Goward et al 2005).

There are convincing arguments that raising children is indeed economic activity (Pocock 2003) but this understanding is sinking into public consciousness slowly, if at all. The work involved is mostly treated as 'caring': an intangible that expresses feelings and commitments, rather than as tangible work that takes up time and energy. 'The' economy continues to mean the market economy. Care of young children remains marginalised, treated within the economy as a private matter like a hobby or having a pet. However, time spent on caring for young children is committed time rather than discretionary time, and there is little capacity to reduce the time spent. This time comes at a cost to parents and provides a benefit to the whole community, a clear exploitation of the labour of parents (mostly mothers).

\section{Social Policy Significance}

Within Australian social policy, women are increasingly perceived as individuals rather than subsidiary household members, and as having some entitlement to economic wellbeing. The male breadwinner female homemaker model is generally seen as no longer valid, but many labour market and social policy provisions have not kept pace with this cultural change. New structural arrangements are difficult to achieve, and will require major shifts in ways of thinking about situations, and examination of evidence not previously considered important. The design of appropriate maternity and paternity leave, family allowances, childcare, education, training and labour market practices require detailed information about the time required to care for children of different ages, and the costs to various parties of raising children.

Before having children, women may see childbearing as a temporary interruption to income earning. However, evidence available to date indicates that it is more of a permanent setback. Women who specialise in unpaid work may see themselves as being in partnership with male partners who specialise in paid work. However, for the many women whose desires change; who find themselves heading single-parent households; or are alone later in life, the degeneration of their earning capacity has serious consequences possibly including poverty for themselves and their children.

\section{Methodology}

When considering income as an indicator of wellbeing, it is important to consider income from all sources. This study had two data requirements - a large enough data set to allow for fine analysis of the data by gender, family type and age of youngest child; and data on total income rather than earnings alone. Labour market income reflects individuals' ability to engage in paid employment, but total income from all sources including government transfers, income from investments and self employment is a better indicator of ability to meet the expenses of everyday life. There are three credible Australian sources of income data - the Australian Bureau of Statistics (ABS) Survey of Income and Housing (SIH); longitudinal studies including HILDA (Household, Income and Labour Dynamics Australia) and the ABS census, conducted every five years. The only data set that meets both the criteria for this research is the ABS census, and customised census data was used.

The most recent data available at the time of writing was the 2001 Australian Bureau of Statistics census data. The question about income on the 2001 Australian census asked people to nominate an income range from a list provided. The instructions said to include income from all sources, specifically mentioning wages and salary, Centrelink benefits and pensions, superannuation, self-employment and investments. The data are reported in income ranges. For this study, average incomes were calculated using the midpoints of the ranges. Following these calculations, the low income ranges were 
reconfigured, collapsing some of the categories, in order to have more even ranges for the graphs. It was not possible to split the top three ranges, and these are presented as provided by the ABS.

This research focused on incomes of women and men with dependent children. Previous research indicates that there are differences in time use, earnings, and labour market participation between women and men, and between couple-family mothers and single mothers. This research adds attention to single fathers. The most suitable ABS census variable for studying these groups is 'Family Type'. The reported values of this variable are 'Couple family with children'; 'Couple family without children'; 'One parent family'; 'Other family'; and 'Not applicable'. 'Other family' includes households with dependent children whose parents are not part of the household. 'Not applicable' includes households without dependent children. This variable is coded by ABS staff depending on information given on the census form, particularly the stated relationship between the reference person and other adults in the household. Because of this procedure, 'Couple family' includes married, de facto and same-sex couples if their answers to census questions indicate these relationships. 'One parent family' includes single adults who identify themselves as the parent of at least one child, either resident with them on census night or usually resident with them. Where there is substantial sharing of care of children between parents who are both single, both parents could be identified as 'One parent family' even though the child/ren could have been with only one of them on census night.

The preliminary data analysis revealed a much higher proportion of male-headed single parent families than is usually cited. The statistic usually quoted in relation to proportion of female-headed and maleheaded single families is 83 per cent female headed, or approximately five times as many female-headed as male (ABS 2003). However, using the 'Family Type' variable, I found that $30 \%$ of single parent families were male-headed. Within 'One parent families', 70 per cent were single mothers, 2.3 times as many as single fathers. This is a useful distinction, because it reflects contemporary patterns of separated parents taking responsibility for children rather than old ideas of 'custodial' or even 'resident' parent, within which a 'main' parent must be identified.

This article reports on average weekly incomes and income distributions for women and men in single families and couple families. A separate article reports on average weekly incomes by age of youngest child (Grace 2007). While the ABS census is a large and relatively accurate data set, it has some limitations, including that it does not include absolutely all persons in Australia, and that there is the possibility of some systematic mis-reporting in relation to income data. Because of concerns about the reliability of bottom decile income data, researchers often exclude this decile, particularly in studies of income inequality, and compare the top decile with the second decile (see for example ABS 2005). For this research I have retained the first decile, including the nil and negative income categories as I believe the picture is incomplete without them. Whether or not these categories reflect 'real' incomes, they do reflect reported incomes, and may be read in this way.

\section{Findings}

Comparisons of women's and men's incomes are usually based on earnings, indicating that women's earnings are about $68 \%$ of men's (ABS 2005). My analysis of census data found that women's average gross weekly income from all sources was approximately $60 \%$ of men's. Looking at Australians in different family types, I found as expected that women with dependent children had lower incomes than women without dependent children. In contrast, men with dependent children had higher incomes than men without dependent children. These findings are consistent with the view that the presence of dependent children puts pressure on women to spend their time on caring for the children rather than earning money, and pressure on men to maximise income (Russell et al 1999). 
Table 1: Average weekly incomes of Australian women and men with and without dependent children

\begin{tabular}{|l|l|l|l|}
\hline & Females & Males & F:M Ratio \\
\hline All persons (aged15+) & $\$ 370.88(\mathrm{n}=3,914,499)$ & $\begin{array}{l}\$ 615.73 \\
(\mathrm{n}=3,700,898)\end{array}$ & $60 \%$ \\
\hline $\begin{array}{l}\text { Without dependent } \\
\text { children }\end{array}$ & $\begin{array}{l}\$ 407.64 \\
(\mathrm{n}=596,184)\end{array}$ & $\begin{array}{l}\$ 558.89 \\
(\mathrm{n}=695,033)\end{array}$ & $73 \%$ \\
\hline With dependent children & $\begin{array}{l}\$ 364.60 \\
(\mathrm{n}=3,318,315)\end{array}$ & $\begin{array}{l}\$ 629.04 \\
(\mathrm{n}=3,005,865)\end{array}$ & $58 \%$ \\
\hline
\end{tabular}

Australian mothers tend to specialise in the unpaid work of caring for children and fathers tend to specialise in paid work. Because of this, we would expect fathers' weekly incomes to be higher than mothers'. This was the case, with mothers' incomes sitting at just $58 \%$ of fathers'. Table 2 shows how this picture changes if we look at different family types.

Table 2: Average weekly incomes of Australian women and men with dependent children by family type

\begin{tabular}{|c|c|c|c|}
\hline & Females & Males & F:M Ratio \\
\hline Couple family with children & $\begin{array}{ll}43 & \$ 356 . \\
10,129)^{(n=2,6}\end{array}$ & $\begin{array}{ll} & \$ 662 . \\
91 & (n=2,6\end{array}$ & $54 \%$ \\
\hline One parent family & $25{ }_{9,950)} \quad \begin{array}{l}(\mathrm{n}=65 \\
\end{array}$ & $49 \quad \begin{array}{l}352 . \\
4,622)\end{array} \quad(n=28$ & 113 \\
\hline Other family & $\begin{array}{ll}85 & \$ 359 . \\
0,500) & (n=42\end{array}$ & $\begin{array}{ll}45 & \$ 396 . \\
9,465) & (n=51\end{array}$ & $91 \%$ \\
\hline Couple family without children & $\begin{array}{ll}64 & \$ 468 . \\
5,684) & (n=17\end{array}$ & $\begin{array}{ll}80 & \$ 627 . \\
5,568) & (n=17\end{array}$ & $75 \%$ \\
\hline Other persons & $\begin{array}{ll}15 & \$ 382 . \\
0,500) & (n=42\end{array}$ & $\begin{array}{ll}60 & \$ 535 . \\
9,465) & (n=51\end{array}$ & $71 \%$ \\
\hline
\end{tabular}

Within couple families with children, women's incomes are under $\$ 400$ per week, much lower than men's, at $54 \%$. Couple-family men with children have the highest incomes (over $\$ 650$ per week) of any of these groups, including couple-family men without children. This pattern supports the idea that having children puts downward pressure on women's incomes and upwards pressure on men's incomes.

In couple families without dependent children (see Table 2), women had higher incomes than women in other family types, and men had higher incomes than other men except for couple-family men with dependent children. These couple families without dependent children would include couples who have not had children and those who previously had dependent children. The women's incomes are higher than those of women in any of the other family types, but still under $\$ 500$ per week, and just $75 \%$ of 
men's. This probably reflects a complex picture of advantage and disadvantage. The disadvantages would include the gender segmentation of the labour market and the lifetime impacts of childbearing. The advantage would probably flow from the support and sharing of responsibilities with a life partner. The women's incomes in this group are higher than the couple-family-with-dependent-children women, reflecting women's greater earning capacity when they are not responsible for children.

The most surprising finding from this research relates to incomes for one-parent families. This analysis of census data suggests that single mothers have higher average weekly incomes than single fathers. This runs counter to my expectation that single mothers would be the most disadvantaged of these groups in terms of income.

\section{Single parents' incomes}

Logically, one might imagine that for every single mother in Australia there would be a single father. However, if single men do not list their children as 'usual residents' in their household, they would not be classified as 'single parent households' by the ABS. If fathers have re-partnered, they would show as 'couple families'. We know that men are more likely than women to re-partner, and also that mothers post-separation continue to take major responsibility for children. These factors explain the big difference between numbers of single mothers and single fathers.

I am assuming that where there is shared parenting (50/50 or 60/40) both parents would include the child or children as usual residents, and would be classified as single parent families by the ABS. Testing this assumption would be an appropriate activity for census researchers.

\section{Incomes by gender and family type}

Tables 1 and 2 focus on average weekly incomes. However, understanding the distribution of incomes within family types is equally important. Figure 1 presents income distributions for all Australian women and men aged $15+$ in different family types.

Figure 1: Incomes of women and men with dependent children, Australia 2001

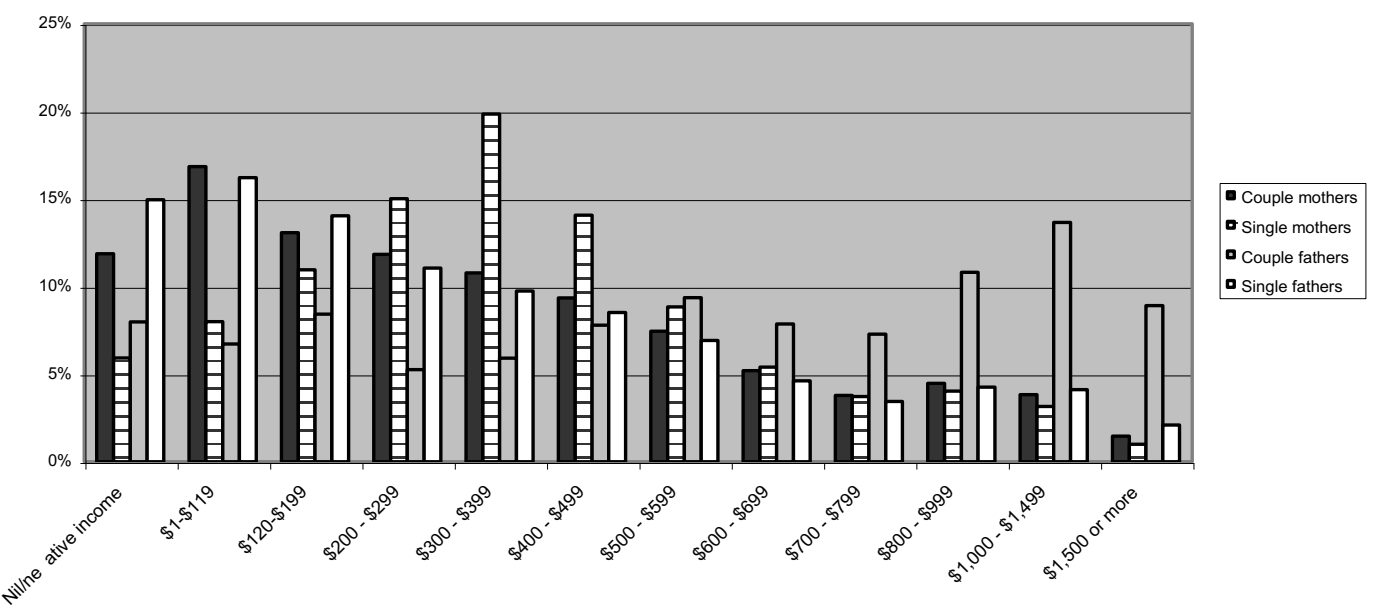

Within each cluster, reading from the left, the first bars are the couple mothers. The second bars are the single mothers. The third bars are the couple fathers and the fourth bars are the single fathers.

The couple fathers have a tri-modal distribution with plenty of activity at the upper income levels. The other groups are all relatively unlikely to have incomes over $\$ 700$ per week. Single mothers are more likely than other groups to have incomes between $\$ 200$ and $\$ 500$ per week. It may be that single mothers are more likely than single fathers to count their Centrelink payments as income. However, this is an untested assumption. This finding may reflect greater social pressure and expectation on single 
mothers to have labour market earnings in addition to Centrelink payments than on either couple family mothers or single fathers.

Responsibility for children clearly has a significant impact on income. This study shows a likelihood of low incomes for both mothers and fathers who remain single post-separation. Couple-family mothers also had low individual weekly incomes. Only couple-family fathers were likely to have high incomes. Overall, these findings support the idea that the labour market is set up for the 'ideal worker' (Williams 2000), a man with the pressure of children at home to support, and a wife or partner at home to do his share of the unpaid work.

\section{Conclusion}

Families with dependent children need time, income and services in order to carry out the important function of raising children, an essential social and economic activity that ensures the future survival and wellbeing of the society. The research reported in this article shows that in Australia only couplefamily fathers are likely to have comfortable incomes. We need social policy that takes account of diversity of family forms; makes it possible for all families raising children to gather together adequate income; encourages gender equity; and acknowledges the raising of children as activity that benefits the whole community. Along with these requirements, social policy must recognise that caring for children takes time, and that the demands of children change over the lifecourse. The lifecourse considerations include the high demands on parental time in the early years; and recognition of change in roles and circumstances over time.

For most Australian women who take time out from the labour market, this is a temporary arrangement, not a sign of taking up a life-long identity as a 'stay-at-home mother'. Many women and some men mix their parenting and labour market activities, challenging the juxtapositioning of 'working' and 'staying at home'. In relation to 'single mothers', far from being a fixed category, today's single mother was probably previously a married mother, and she may be a couple-family mother in the future.

Social policy that relies on fixed categories cannot hope to respond to contemporary lives. We need policies that take account of diverse lifecourse experiences, including early parenting, same-sex couple parenting, single parenting and shared parenting. Critical aspects include the very high demands infants and young children make on parental time; and the desires and needs of both women and men to participate meaningfully in both paid employment and direct caring for children. Families raising children need adequate income at all stages of the lifecourse; large amounts of time for direct childcare while children are very young; flexible time for child-related commitments as children reach school age; and appropriate services including health, education, support and childcare.

Better social policy would enable parents to get through the intensive early years of children's lives while keeping future options open. Babies and toddlers up to two or three years of age require many hours of intensive work. This care is expensive to provide in childcare centres, and it is expensive to provide at home. It is reasonable for the community in general to bear the dollar costs of this care, whether through free childcare, paid maternity/paternity leave or a generous short-term (for example three years) parenting allowance. Of course, some assistance with the costs of children should continue in the longer term. If families sink into either poverty or stereotypical gender roles in these early years, the data indicate that they may never recover. However, if the community offers generous support for early parenting, families have a strong platform for establishing longer-term wellbeing, including the ability to earn a good income once their children are older.

Better social policy would encourage parents to share caring responsibilities and income-earning rather than specialising in one or the other. Current policy punishes this arrangement relative to a breadwinner / homemaker model, as families with two part-time incomes lose Family Tax Benefit Part B, even though their two part-time incomes may amount to no more than one full-time income. As well as promoting gender equity, supporting sharing would reduce the degeneration of mothers' earning capacity, thus protecting to some extent against single parent poverty in the event of couple separation. 
This research suggests that single parenthood is no longer overwhelmingly single mothers taking sole responsibility for their children. The 70:30 ratio of single mothers to single fathers may indicate more single fathers taking sole responsibility for children. However, it seems likely that much more single parenthood than in the past consists of separated couples sharing responsibility for children. The income data indicate that many single parent families are suffering from lack of adequate income. We need to develop new ways of assisting single parent families. Better support of these households could include, for example, both parents having full entitlement to Family Tax Benefits.

For parents with limited earning capacity, perhaps because early parenthood has interrupted education, incentives to undertake education and training while youngest child is aged 3-8 would increase future earning capacity. More generous arrangements would be a sensible investment in future family wellbeing.

Present social arrangements partly recognise the responsibility of the rest of the community to contribute to the costs of raising children, with Family Tax Benefit A and B, maternity payment, and health and education services. Some of Australia's provisions are moving away from stigmatised welfare payments, but they are far from Nancy Folbre's (2005) recommendation that government transfers to parents should be treated as payments for services rather than as welfare payments.

This study has presented a new way of looking at income data. It is a preliminary study, establishing a broad general picture. It highlights the need for further research into incomes following childbearing, and the ways that incomes vary among women and men in different family types.

\section{References}

Australian Bureau of Statistics (2005) 'Household income and wealth' in Year Book Australia, Cat. No. 1301.0, Canberra.

Australian Bureau of Statistics (2003). Australian Social Trends, Cat No 4102.0, Canberra.

Australian Institute of Family Studies (2000) A Guide to Calculating the Costs of Children, AIFS, Melbourne.

Bittman, Michael \& Pixley, Jocelyn (1997) The Double Life of the Family: Myth, Hope and Experience, Allen \& Unwin, St Leonards, NSW.

Breusch, Trevor \& Gray, Edith (2004) 'New estimates of mothers' foregone earnings using HILDA data', Australian Journal of Labour Economics, v.7, no.2, pp. 125-150.

Brown, Stephanie, Lumley, Judith, Small, Rhonda \& Astbury, Jill (1994) Missing Voices: The Experience of Motherhood, Oxford University Press, Melbourne.

Cass, Bettina, (2005) 'Women as carers: economic and social aspects of caring', paper presented at the Women, Aging and Participation workshop, Commonwealth Office for Women, Brisbane 26-5-05.

Craig, Lyn (2007) 'Contemporary motherhood: The impact of children on adult time', Ashgate Publishing, Aldershot, Hampshire.

Craig, Lyn (2004) 'Time to care: A comparison of how couple and sole parent households allocate time to work and children', SPRC Discussion Paper No 133, Social Policy Research Centre, University of New south Wales, Sydney.

Craig, Lyn (2002) 'The time costs of parenthood: an analysis of daily workload', SPRC Discussion Paper No 117, Social Policy Research Centre, University of New south Wales, Sydney.

Evans, M. D. R. and Kelley, Jonathan (2001) 'Employment for mothers of pre-school children; Evidence from Australia and 23 other nations', People and Place, vol. 9 no. 3, pp 28-40.

Folbre, Nancy (2005) 'Our children, ourselves: rethinking the economics of family policy', Australian Social Policy conference, University of New South Wales, Sydney, 20-22 July 2005. Available http://www.sprc.unsw.edu.au. Viewed 15-8-05.

Gilding, Michael (1994) 'Gender roles in contemporary Australia', in Contemporary Australian Feminism, (ed.) K. Hughes, Longman Australia, Melbourne, pp. 102-127. 
Grace, M. (2007) ‘Australian women's and men's incomes by age of youngest child', Journal of Business Systems, Goverance and Ethics, vol. 2, no. 2, pp.47-57. Available at http://www.jbsge.vu.edu.au

Gray, Matthew and Chapman, Bruce (2001) 'Foregone earnings from childrearing: changes between 1986 and 1997', Family Matters, no. 58, pp. 4-9.

Goward, Pru et al (2005) Striking the Balance: Women, Men, Work and Family, Discussion Paper, Sex Discrimination Unit, Human Rights and Equal Opportunity Commission, Sydney.

Hakim, Catherine (2003) Models of the Family in Modern Societies: Ideals and Realities, Ashgate, Burlington, VT.

Hakim, Catherine (1996) Key Issues in Women's Work: Female Heterogeneity and the Polarisation of Women's Employment, Athlone, London.

Hughes, Katie (ed.) (1994) Contemporary Australian Feminism, Longman Australia, Melbourne.

Ironmonger, Duncan (2001) 'Caring for kids: the greatest economic use of time', Paper presented at IATUR Conference, Oslo, Norway, October 3-5, 2001.

McDonald, Peter (2000) 'Gender equity, social institutions and the future of fertility', Journal of Population Research, Vol. 17, No.1, pp. 1-16.

Ministerial Taskforce on Child Support (2005) In the Best Interests of Children: Reforming the Child Support Scheme, Department of Family and Community Services, Canberra. Available http://www.facs.gov.au/internet/facsinternet.nsf/family/childsupportreport.htm Viewed 3-10-05.

Morehead, Alison (2005) 'Governments, workplaces and households: to what extent do they shape how mothers allocate time to work and family, and what role do preferences play?' Family Matters, No $70, \mathrm{pp}$.

O’Connor, Julia, Orloff, Ann, \& Shaver, Sheila (1999) States, Markets, Families: Gender, Liberalism and Social Policy in Australia, Canada, Great Britain and the United States, Cambridge University Press, Cambridge.

Office of the Status of Women (OSW) (2002) Women in Australia, Office of the Status of Women, Canberra.

Percival, Richard and Harding, Ann (2005) 'The estimated costs of children in Australian families in 2005-06', Commissioned research report for the Ministerial Taskforce on Child Support, National Centre for Social and Economic Modelling, University of Canberra.

Pocock, Barbara (2003) The Work/Life Collision: What Work is Doing to Australians and What to do About it, Federation Press, Annandale, N.S.W.

Probert, Belinda \& Murphy, John (2001) 'Majority opinion or divided selves? Researching work and family experiences', People and Place, Vol. 9, No. 4, pp. 25-33.

Russell, Graeme et al (1999) Fitting Fathers into Families: Men and the Fatherhood Role in Contemporary Australia, report prepared for the Commonwealth Department of Families and Community Services, Canberra. Available http://www.facs.gov.au. Viewed 15-8-05.

Shaver, Sheila and Burke, Sharon (2003) 'Welfare states and women's autonomy: A thought experiment', paper presented at the Australian Social Policy Conference, 9-11 July, University of New South Wales.

Silvey, Jerry and Birrell, Bob (2004) 'Financial outcomes for parents after separation', People and Place, vol. 12, no. 1, pp. 46-57.

Smyth, Bruce, Caruana, Catherine and Ferro, Anna (2003) 'Some whens, hows and whys of shared care: What separated parents who spend equal time with their children say about shared parenting', paper presented to the SPRC Conference 9-1 $1^{\text {th }}$ July 2003, Sydney.

Walters, Maggie (2002) 'Labour market participation and the married to sole mother transition', in T. Eardley and B. Bradbury eds. in Competing Visions: Refereed Proceedings of the National Social Policy Conference 2001, SPRC Report 1/2, Social Policy Research Centre, University of New South Wales, Sydney, pp. 411-421.

Williams, Joan (2000) Unbending Gender : Why Family and Work Conflict and What to do About it, Oxford University Press, New York.

Wolcott, Ilene \& Glezer, Helen (1995) Work and Family Life: Achieving Integration, Australian Institute of Family Studies, Melbourne. 
